\title{
The Phenomenon of Political Correctness in Modern English
}

\author{
Anna Monashnenko ${ }^{1}$ Svitlana Amelina ${ }^{1,{ }^{*}}$ Vasyl Shynkaruk ${ }^{1}$ \\ ${ }^{1}$ National University of Life and Environmental Sciences of Ukraine, Ukraine \\ ${ }^{*}$ Corresponding author.Email: svetlanaamelina@ukr.net
}

\begin{abstract}
The paper deals with the phenomenon of political correctness in modern English. The socio-cultural and linguistic aspects of political correctness are highlighted. The paper focuses on the search for new means of linguistic expression and the adjustment of the language code as the main characteristics of the linguistic manifestation of political correctness. It is determined that the use of euphemisms is one of the elements of the technology of political correctness. The classification of groups and subgroups of euphemisms based on the thematic fields they serve is proposed. The quantitative ratio of the frequency of using euphemisms of different groups was determined. It was found that the highest percentage of euphemisms is associated with racial and gender discrimination.
\end{abstract}

Keywords: political correctness, euphemism, thematic group of euphemisms, euphemistic substitutions.

\section{INTRODUCTION}

Political correctness is a kind of voluntary social code of conduct that has developed spontaneously in the West. It is based on a very approving desire not to offend, not to touch a person's feelings, to preserve the dignity and good mood. This is achieved through the inadmissibility of the derogatory mentions of physical or mental disabilities of the third parties, their racial, religious or national affiliation, gender equality in public and private life, measures against sexual harassment at work, as well as the prevention of contempt, derogatory remarks and aggressive attacks on address those people who consider themselves sexual minorities, if their behavior does not go beyond the law.

Political correctness is not just a replacement for concepts such as politeness or tolerance; it is a whole policy and a certain way of behaving.

The purpose of this paper is to analyse the phenomenon of political correctness in modern English, in particular the linguistic aspect of this phenomenon and to identify thematic groups of euphemisms that are used for reasons of political correctness.

\section{LITERATURE REVIEW}

The term "political correctness" or "politically correct" means the formation of language behavior to minimize or avoid discrimination against certain social groups: national, ethnic, religious and sexual minorities, women, people with disabilities, different social status, the elderly etc.

Approaches to the analysis of political correctness are different: the latter is interpreted as a special ideological reality, language movement, culturalbehavioral and language tendency, language tolerance, and so on. It is necessary to agree with the failure of the term "political correctness" (mainly due to the first component in this phrase, which acquired, due to known circumstances, a negative colour in Ukraine), but it is also necessary to state its stability and inclusion in many languages [9: 85].

Despite its widespread use, the topic of political correctness has not received, in our opinion, a sufficiently complete understanding in the scientific literature, especially in linguistic research. Mainly researchers from the United States consider problems related to the political correctness as a phenomenon inherent in American culture. The works of D. Adler, R. Bell, J. Bleifuss, F. Ellis, and R. Lakoff, in 
particular, are devoted to political correctness and related issues etc.

A distinctive feature of the most publications of these American authors is the interpretation of political correctness as one of the elements of the US educational doctrine. Meanwhile, the actual linguistic aspect of political correctness in the works of these authors is either not affected at all, or recedes into the background.

In the countries of the former USSR, the problems of political correctness are considered in a limited number of scientific studies. These are, first, the works of A.V. Ostroukh "Political correctness in the USA: culturological aspect of the problem" (1998), Y.L. Humanova "Political correctness as a sociological process" (1999), monograph by S.G. TerMinasova "Language and Intercultural Communication" (2000) and some others.

It is difficult to trace the history of this term, as there are different opinions about the exact date of its origin. Some believe that Caren de Crow president of the National Women's Organization in 1975 first introduced the concept of "political correctness", while others attribute the term to 1793, when the Supreme Court of the United States heard the case of Chisholm vs. Georgia. It was also used the terms politically incorrect, socially unacceptable. It is also thought that it was first used in 1987 in Alan Bloom's bestseller "The Closing of the American Mind". Despite the fact that the origin of this concept is still controversial, it is clear that the ideology of political correctness that emerged on American campuses in the 70 s of the twentieth century became widespread and reflected in the English language. Thus, we can conclude that the concept of "political correctness" is multifaceted and the question of its origin is still open.

We propose to consider the main interpretations of this concept, because there are serious differences.

The definition is given in the "Dictionary of new words and meanings" by Z.S. Trofimov, shows that "political correctness" appeared in connection with the emergence of the idea of cultural pluralism and the consequent need in accordance with the new ideology to proportionally present works of literature and art, achievements of social and political life, belonging to all ethnic and sexual minority" [13:245].

N.G. Komlev's "Dictionary of Foreign Words" provides the following definition: "Political correctness which has been established in the United States as a concept-slogan, demonstrates the liberal orientation of modern American politics.
Political correctness deals not so much with content as with symbolic images and correction of the language code. The language is decorated with signs of anti-racism, environmentalism, tolerance of national and sexual minorities, the fight against AIDS. Tolerance manifests itself in softened expressions" [5:367].

According to Collin's Dictionary, political correctness is "demonstrating progressive ideals, especially by avoiding vocabulary that is considered offensive, discriminatory, or judgmental, especially concerning race and gender" [1].

S.G. Ter-Minasova believes that "the political correctness of language is expressed in the desire to find new ways of language expression instead of those that affect the feelings and dignity of the individual, oppress his human rights with habitual language tactlessness and straightforwardness regarding race and gender, age, health, social status, appearance, etc." [12:15].

In general, S.G. Ter-Minasova considers the expedient to replace the term "political correctness" with a more appropriate one, namely the phrase "language tact". Indeed, it would be more correct to translate the English term into Ukrainian as "ethical / communicative / cultural correctness", because, as mentioned above, the concept of "political" in the Ukrainian language has a negative connotation.

Foreign authors argue that the phenomenon of political correctness has emerged and spread in the US colleges and universities due to the ethnic and racial diversity of students and define political correctness as "a network of interconnected ideological beliefs that call into question the foundations of university education: traditional curriculum, views on objectivity of the received knowledge, giving value to cultural, sexual, class and racial differences" [10:106].

\section{RESULT AND DISCUSSION}

\subsection{The linguistic aspect of political correctness}

The phenomenon of political correctness is associated with a change in language norms in English at the present stage. This is primarily expressed in the creation of certain restrictions or a complete prohibition on the use of certain words and phrases in a particular situation. It should be noted that a number of terms have been formed different types of discrimination: ableism - discrimination against people with disabilities; ethnocentrism discrimination human cultures other than the 
dominant; heterosexism - discrimination the rights of people with different sexual orientations; lookism creating standards of attractiveness and beauty and discriminating against people who do not meet such standards; ageism - discrimination against the elderly; hightism - discrimination against tall people; classism - class discrimination.

It should also be noted that the concept of "political correctness" has given to a number of related concepts, namely: "eco-correctness" - correct ecological policy, the right attitude to the environment; "emotional correctness" - accepted feelings and emotions in society; "dress correctness" - adopted uniforms; "religious correctness" - tolerance of representatives of different religions.

Thus, political correctness is interpreted as:

- the tendency manifested in the desire to find new ways of language expression instead of those that affect the feelings and dignity of the individual habitual language tactlessness and straightforwardness regarding race and gender, age, health, social status, appearance, etc. [14:16];

- behavioral and linguistic phenomenon that reflects the desire to overcome existing speakers in the community and society perceived discrimination against various members of the society [14:22];

- ideological-political movement in the $80-90$ s years in the US, which spreads mainly within liberal groups and that is imposing strict compliance neutral language regarding gender, height, sexual orientation, race, civil rights and restrict freedom of speech in the discussion of the above topics [11:158].

Analysis of definitions allowed us to identify two most important aspects of political correctness:

1. Socio-cultural aspect closely related to ideology and politics, especially in the field of education;

2. Linguistic aspect, which is manifested in the search for new meaning of the linguistic expression and the correction of language code.

\subsection{The use of euphemisms as a technology of political correctness}

Political correctness requires the use of technology to replace offensive terms with neutral words and expressions - euphemisms.

Euphemism - euphemia (from Greek) - is a restraint from inappropriate words, softened expression -replacement of rough or harsh words and expressions with softer ones.
Euphemism is the result of lexical taboos (prohibitions), which through various kinds of prejudice, superstition, and religious beliefs imposed on the use of certain names of objects and phenomena of the world, so that people resort to indirect expressions. At the beginning of human history, verbal taboos included lexical units that referred to supernatural forces, denoting death, disease, and natural phenomena. Human's idea of the world has changed, and with it has changed the idea that it should not be "called by the name." The mythological worldview of the polytheistic tribes underwent a number of transformations and eventually gave way to the secular worldview, although its remnants are still felt in superstitions and so on.

Over time, the emphasis shifted to sexual themes. At present, euphemisms are the result of political manipulation and commercial tasks.

Given the large number of euphemistic substitution variants that have appeared in the language, it seems appropriate to try to classify them, thus clearly demonstrating the thematic fields covered by politically correct vocabulary. We attempted to classify such substitutions (Table 1).

A necessary condition for the political correctness of language is to avoid the use of lexical items that may discriminate against the addressee in terms of age, gender, physical condition, social status, race and cultural affiliation. Thus, politically incorrect vocabulary consists of euphemisms that help to avoid negative evaluative prospects of expression.

Euphemism is the process of gradually acquiring a word or phrase, which a modern lexicology is defined as an emotionally neutral word or expression used instead of a taboo or synonymous word (expression), pragmatic reasons [6:63].

Euphemism (euphémia (from Greek) - is an abstinence from inappropriate words, softened expression) - replacing rough or harsh words and expressions with softer ones, as well as some proper names - symbols [4:116].

Euphemisms are words and phrases that appear in a language to denote concepts that already have names but are considered unpleasant, rude, obscene, or low for some reason. They are in the vocabulary of the language and are synonymous with words that previously denoted these concepts [7:58].

Euphemisms are the substitution of one notation for another, a softened one. This mitigation does not distort the concept, does not lead to a misinterpretation of the concept. As someone who uses the euphemism, 
and one who perceives understand the significance of this change [7:59].

Table 1. Euphemistic substitutions

\begin{tabular}{|c|c|c|}
\hline $\begin{array}{c}\text { Thematic group of } \\
\text { euphemisms }\end{array}$ & Subgroup & $\%$ \\
\hline \multirow{5}{*}{\begin{tabular}{l}
\multicolumn{1}{c}{ I } \\
Euphemisms \\
associated with \\
groups of people that \\
exposes \\
discrimination
\end{tabular}} & $\begin{array}{l}\text { 1. racial discrimination, } \\
\text { cultural, religious }\end{array}$ & 21 \\
\hline & $\begin{array}{l}\text { 2. sexual } \\
\text { discrimination }\end{array}$ & 19 \\
\hline & $\begin{array}{l}\text { 3. discrimination } \\
\text { against sexual } \\
\text { minorities }\end{array}$ & 3 \\
\hline & $\begin{array}{l}\text { 4. discrimination in } \\
\text { general (in relation to } \\
\text { all groups) }\end{array}$ & 4 \\
\hline & $\begin{array}{l}\text { 5. other types of } \\
\text { discrimination }\end{array}$ & 0,8 \\
\hline \multirow{5}{*}{$\begin{array}{l}\text { II } \\
\text { Euphemisms } \\
\text { denoting terrible and } \\
\text { unpleasant } \\
\text { phenomena of reality }\end{array}$} & 1. death & 1 \\
\hline & 2. diseases & 3,5 \\
\hline & 3. natural needs & 0,2 \\
\hline & 4. physical disabilities & 4,5 \\
\hline & $\begin{array}{l}\text { 5. mental and } \\
\text { psychiatric disorders }\end{array}$ & 2,7 \\
\hline \multirow{8}{*}{\begin{tabular}{l}
\multicolumn{1}{c}{ III } \\
Euphemisms \\
associated with the \\
influence of the state \\
on people's lives
\end{tabular}} & 1. military action & 0,6 \\
\hline & $\begin{array}{l}\text { 2. social vices } \\
\text { (drunkenness, drug } \\
\text { addiction, prostitution, } \\
\text { homelessness, crime, } \\
\text { lies) }\end{array}$ & 5 \\
\hline & 3. poverty & 5,7 \\
\hline & $\begin{array}{l}\text { 4. non-prestigious } \\
\text { professions }\end{array}$ & 1,8 \\
\hline & 5. family & 1,7 \\
\hline & $\begin{array}{l}\text { 6. institutions of state } \\
\text { supervision }\end{array}$ & 0,5 \\
\hline & 7. quit & 1,9 \\
\hline & 8. academic failure & 2,5 \\
\hline \multirow{4}{*}{\begin{tabular}{l}
\multicolumn{1}{c}{ IV } \\
Euphemisms \\
denoting appearance \\
and age of the \\
person
\end{tabular}} & 1. weight & 2,3 \\
\hline & 2. age & 1,9 \\
\hline & 3. appearance & 2,3 \\
\hline & 4. height & 0,9 \\
\hline \begin{tabular}{l}
\multicolumn{1}{c}{$\mathrm{V}$} \\
Euphemisms, \\
indicating human \\
impact on flora and \\
fauna
\end{tabular} & & 3,5 \\
\hline \begin{tabular}{l}
\multicolumn{1}{c}{$\mathrm{VI}$} \\
Humorous \\
euphemisms \\
(parodies of political \\
correctness)
\end{tabular} & & 9,7 \\
\hline
\end{tabular}

V.I. Hoverdovsky writes that forms of politeness and observance of the rules of language prohibitions do not often allow the use of vocabulary with a direct meaning [2:66]. This may explain the origin of the euphemism pseudologer - one who tells a lie - instead of a word liar. In colloquial speech, the prefix pseudoused as a euphemism for words with a direct meaning "bad or false quality" [2:66].

Euphemism is a consequence of the lexical taboo (prohibition), which due to various prejudices, superstitions, and religious beliefs is imposed on the use of the names of certain objects and phenomena of the world, because of which a person resorts to expressions of allegory. Characteristically, the new designations of "obscene" objects and phenomena over time lose the character of euphemisms, begin to be perceived as a direct reference to the "obscene" object and in turn become "obscene".

Underlying the phenomenon of euphemism are:

1. Deeply archaic remnants of linguistic "taboos" (prohibitions to pronounce direct names of such dangerous objects and phenomena as, for example, gods, diseases or the dead, because the act of the name, according to the logical thinking of primitive man, can cause the phenomenon itself) - such euphemisms such as: "unclean" instead of "devil", "deceased", "dead";

2. Factors of social dialectology, i.e. the basis of dialectical development are social factors - the presence or absence between the relevant areas of cultural and economic ties both in the present and in the past.

A large group of euphemisms is created on the principle of politeness. This group usually includes words and expressions that alleviate various types of discrimination.

1. Euphemisms that mitigate age discrimination. It appeared even the term "ageism" oppression of people of a certain age. In order not to offend, for example, people of respectable age, the word middlescence has appeared in the language of recent decades (similar to adolescence), a period of life from 40 to 65 years. People over 65 were called third age. Avoid using the word old, instead of common euphemisms such as senior, mature and seasoned.

2. Euphemisms that mitigate property discrimination. The reason for the creation of such euphemisms is often the desire of authorities of various ranks to smooth out the problems of a property inequality. As G.D. Tomakhin writes, "word the poor in the press was replaced by the needy, the illprovided, then on the deprived, then on the socially deprived, the underprivileged, and later on the disadvantages (who found themselves in less 
favorable circumstances), and finally on low-income people [8:113].

3. Euphemisms that exclude discrimination against people with physical and mental disabilities. Almost every shortcoming is smoothed out by certain euphemisms: word cripple substitute euphemisms differently abled, physically different or handicapable; fat substitute on big-boned, differently sized; instead bald used hair-disadvantaged; instead deaf-aurally inconvenienced; instead blind - unseeing. Mentally retarded people are called learning disable, special, mentally challenged people.

4. Euphemisms that mitigate racial and ethnic discrimination. Such words are mainly the names of different racial and national groups, emphasizing their identity and equal status. Word black is replaced by a euphemism member of the African diaspora. Indianby word indigenous person.

The second layer of euphemistic vocabulary is based on the principle of taboo and aims to reduce superstitious fear of any phenomena (illness, death, etc.). For example, moonchild replaced the word cancer, which causes associations with the disease; hospice, originally means "shelter" or "hotel", now means "hospital for the terminally ill". Insane asylum replaced by word mental hospital; "death of a patient in hospital" is transmitted by euphemism terminal episode, therapeutic misadventure or negative patient care outcome.

The tendency to form new euphemisms, which raise the prestige of certain professions, has noticeably intensified. Thus, hairdresser became known as hairstylist or beautician. The servants in the cemetery have traditionally been known as undertakers, in recent years they have been called morticians, and then funeral directors. Word garbage collector replaced by sanitation engineer, a euphemism environmental hygienist - nothing else as the name of a janitor.

Another group of euphemistic vocabulary is euphemisms, which distract from the negative phenomena of reality. This group should be divided into several subgroups are:

1. Euphemisms that serve the guise of aggressive military action. Many of these words came to the language in the 60 s of the twentieth century during the Vietnam War. Word involvement and conflict replaced by aggression, war, destroy armed resistance became known pacification, instead of word bomb used a word device, and instead of bombing - limited air strike or air support. Euphemism strategic hamlet replaced by concentration camp. Finally, the dead were called body-count or inoperative combat personnel.
2. Euphemisms associated with negative consequences in the socio-economic sphere. During the 20th century economic crisis was squeezed out by slump, slump was replaced by depression, which caused a new euphemism recession. More modern terms in the meaning of the economic crisis include period of economic adjustment, period of negative economic growth, meaningful downturn. To mitigate the negative effect of words firing laying off having euphemisms downsizing, rightsizing, redundancy elimination. The name of the social structure itself "capitalism" has acquired a number of new substitutes in recent decades, no doubt euphemistic: the system of free enterprising, open society, economic humanism [3:371].

3. Euphemisms associated with crime. Euphemism correctional facilities replaced by a word prison, correctional officers or custodial officers replacing the former expression prison guards. The prisoners called clients of correctional system, guests or people enjoying temporarily hospitality from the state.

\subsection{Thematic fields served by politically correct vocabulary}

In Table 2 the thematic fields served by politically correct vocabulary and the percentage of the number of lexical units in each group from the total number of politically correct vocabulary in the sample of 859 language units are given. Due to statistics, it is easy to determine which thematic fields require the greatest euphemism in English-speaking society, i.e. are the most delicate in terms of native English speakers. The issues of racial discrimination have an importance for the tendency to political correctness: the vocabulary of the subgroup "racial, cultural, religious discrimination" is $21 \%$ of the total number of euphemisms. Technical terms slave and master were replaced by words captured device and device therefore, not to offend African-Americans. The expression "Nitty gritty" should not be used because it dates back to slavery. Conversational cliché is also considered incorrect good egg, because "it is very closely related to the phrase egg and spoon, rhyming slang for coon, offensive racist expression ". To avoid insulting anyone's religious feelings Christmas, which means only a Christian religious holiday, offers to replace Winterval (winter + festival), Happy Holidays, Season's Greetings [5:77].

The fight against sex discrimination is extremely important for political correctness: the vocabulary of the subgroup "sex discrimination" is $19 \%$ of the actual material. 
Table 2. Classification of euphemisms by thematic groups

\begin{tabular}{|c|c|}
\hline $\begin{array}{l}\text { Thematic group of } \\
\text { euphemisms }\end{array}$ & Examples \\
\hline \multicolumn{2}{|c|}{$\begin{array}{l}\text { I. Euphemisms that mitigate various types of } \\
\text { discrimination }\end{array}$} \\
\hline 1) age discrimination & $\begin{array}{l}\text { middlescence, third age, } \\
\text { senior, mature }\end{array}$ \\
\hline 2) property discrimination & $\begin{array}{ll}\text { economically } & \text { exploited, } \\
\text { low-income, } & \text { differently } \\
\text { advantaged } & \\
\end{array}$ \\
\hline $\begin{array}{l}\text { 3) discrimination against } \\
\text { people with physical or } \\
\text { mental disabilities }\end{array}$ & $\begin{array}{l}\text { physically challenged, } \\
\text { handicapable, learning } \\
\text { disable, special }\end{array}$ \\
\hline $\begin{array}{l}\text { 4) racial and ethnic } \\
\text { discrimination }\end{array}$ & $\begin{array}{l}\text { person of color, member } \\
\text { of African diaspora, } \\
\text { indigenous person }\end{array}$ \\
\hline $\begin{array}{l}\text { II. Euphemisms that reduce } \\
\text { superstitious fear of any } \\
\text { phenomena }\end{array}$ & $\begin{array}{l}\text { moonchild, hospice, } \\
\text { room of reconciliation, } \\
\text { therapeutic } \\
\text { misadventure }\end{array}$ \\
\hline $\begin{array}{l}\text { III. Euphemisms that } \\
\text { enhance the prestige of a } \\
\text { particular profession }\end{array}$ & \begin{tabular}{|lr} 
hairstylist, & funeral \\
director, & sanitation \\
engineer, environmental \\
hygienist
\end{tabular} \\
\hline \multicolumn{2}{|c|}{$\begin{array}{l}\text { IV. Euphemisms that distract from the negative } \\
\text { phenomena of reality }\end{array}$} \\
\hline $\begin{array}{l}\text { 1) euphemisms that serve } \\
\text { the guise of aggressive } \\
\text { military action. }\end{array}$ & $\begin{array}{l}\text { involvement, device, air } \\
\text { support, } \\
\text { body-count }\end{array}$ \\
\hline $\begin{array}{l}\text { 2) euphemisms that } \\
\text { mitigate the negative } \\
\text { consequences in the socio- } \\
\text { economic sphere }\end{array}$ & $\begin{array}{l}\text { period of economic } \\
\text { adjustment, downsizing, } \\
\text { negative cash flow }\end{array}$ \\
\hline $\begin{array}{l}\text { 3) euphemisms associated } \\
\text { with crime }\end{array}$ & $\begin{array}{l}\text { lorrectional facilities, } \\
\text { custodial officer, client, } \\
\text { guest }\end{array}$ \\
\hline
\end{tabular}

Words with the man or the suffix -ess are considered sexist and are replaced by the word person or a gender-neutral token: gingerbread man gingerbread person. The word God is suggested to be replaced by the phrase Higher Power, because God carries a hint of male superiority.

Thus, the name of the Christmas hymn "God Rest Ye Merry Gentlemen", can be interpreted as "God Rest Ye Merry Persons" or "Higher Power Rest Ye Merry Persons". As an alternative to the term history, which contains the morpheme his, a variant of herstory or she-story is put forward.

$9.7 \%$ of the actual material belongs to the subgroup "humorous euphemisms". This suggests that a large part of the population perceives political correctness ironically.

Humorous euphemisms are created as parodies of those politically correct terms that are "difficult and meaningless." Example, Cattle Concentration Camp (CCC) - cattle ranch, seared mutilated animal flesh (SMAF) - hamburger, where animals are tortured and murdered to fulfill sadistic fantasies of white male scientist lackeys of imperialist drug companies biology department, uniformed fascists vying for superiority - NHL hockey [8:55].

The subgroups "physical disabilities" (4.5\%) and "discrimination against sexual minorities" (3\%) are not represented by a large number of politically correct euphemisms, although the vocabulary denoting these phenomena is widely discussed in the media and is often used to illustrate the language.

Thus, the general classification of euphemisms by thematic groups is presented in Table 2 .

Some researchers also identify the so-called group of political euphemisms, which, however, is erroneous. What is called a political euphemism does not actually have the function of a euphemism, because "political" euphemism in English is an attempt to distort the facts.

Many speeches by American politicians, especially former President Donald Trump, are indicative in this regard:

An unscientific survey seems to suggest that if anything, Mr. Trump is growing more comfortable with crudeness. He used the word "bullshit" in public just once in his first two years in office, according to the Factba.se database that tracks his speeches, but on four occasions in the last three months. "There is no source," he said. "The person doesn't exist. The person's not alive. It's bullshit, O.K.? It's bullshit."

In 2004, as vice president, Mr. Cheney told a senator on the Senate floor to "go fuck yourself."

At one rally during his 2016 campaign, Mr. Trump quoted a supporter calling a Republican rival, Senator Ted Cruz of Texas, a "pussy."

Once taking office, he tried, at least, to keep it private, but he was uninhibited when the cameras were not on. After the special counsel, Robert S. Mueller III, was appointed, he told aides, "I'm fucked." Speaking with lawmakers, he called African nations "shithole countries."

Mr. Trump feigned shock in January when the newly elected Representative Rashida Tlaib of Michigan said she and her fellow House Democrats were "going to impeach the motherfucker."

In a January interview with The Times, Mr. Trump boasted that he had "beat the shit out of" Republican rivals in 2016. A month later, he told the Conservative 
Political Action Conference that his enemies were trying to take him out "with bullshit," a word he then took up with vigor.

He recalled that a consultant tried to make work for himself by identifying environmental concerns on a property Mr. Trump wanted to develop. "I fired his ass so fast," the president recalled.

Trump fluently peppered his answers with words and phrases such as "subsided," "inclination," "discredited," "sparring session," and "a certain innate intelligence." He tossed off well-turned sentences such as, "It could have been a contentious route," and, "These are the only casinos in the United States that are so rated." He even offered thoughtful, articulate aphorisms: "If you get into what's missing, you don't appreciate what you have," and, "Adversity is a very funny thing."

Other sentences are missing words. Again, from the AP: "If they don't treat fairly, I am terminating NAFTA," and, "I don't support or unsupport" leaving out a "me" in the first and an "it" (or more specific noun) in the second. Other sentences simply don't track: "From the time I took office till now, you know, it's a very exact thing. It's not like generalities."

There are numerous contrasting examples from decades ago, including this - with sophisticated grammar and syntax, and a coherent paragraph-length chain of thought - from a 1992 Charlie Rose interview: "Ross Perot, he made some monumental mistakes. Had he not dropped out of the election, had he not made the gaffes about the watch dogs and the guard dogs, if he didn't have three or four bad days and they were real bad days - he could have conceivably won this crazy election."

"'Enormity,' to save you the trouble of looking it up, does not mean greatness size wise. It means 'excessive wickedness.' Such language suits the purposes of our new president, with the apparent consent of the American people. God help us." - Ben Manring, letter in The Indianapolis Star.

In 2008, Barack Obama used the word enormity to mean "great size" a number of times in his speeches. The apparent misuse of this word appalled many people who hold sacrosanct the notion that enormity must only be used to describe things of great wickedness.

Donald Trump: "Who should I fire? Should I fire Maria?" Cyndi Lauper: "I can't..." Donald Trump: "Why don't you just say Maria?" Cyndi Lauper: "Because I feel bad. She's happy now..." Donald
Trump: "Badly. You feel badly." Cyndi Lauper: "Badly." - Donald Trump \& Cyndi Lauper.

In the 9th season of the show, Trump took the opportunity to 'correct' Cyndi Lauper's use of bad (when describing how she felt) to badly. However, it is entirely correct to say 'I feel bad.' The reason that Trump fell victim to this common hypercorrection is that feel is a verb, and many people learned that the word following a verb should be an adverb (badly), rather than an adjective (bad).

Thomas Jefferson was not yet president when a British reviewer scolded him for his coinage of the word belittle, but the reaction to this word was so overheated that it deserves a mention nonetheless. Jefferson had recently published his two-volume work Notes on the State of Virginia (it was released privately in the early 1780 s, and published publicly in 1787), a book which contained the line "So far the Count de Buffon has carried this new theory of the tendency of nature to belittle her productions on this side of the Atlantic."

"Sometimes you misunderestimated me." George W. Bush, News Conference. George W. Bush has attracted considerable scorn for his lapses with the English language. Perhaps none has been commented on so much as his portmanteau misunderestimate. A blend of misunderstand and underestimate, the word was occasionally used by Bush throughout his two terms as President; it saw considerably more use by people who employed it as evidence of Bush's lack of skill with language.

"Peaceful Muslims, pls refudiate" - Sarah Palin. Back in 2010, Sarah Palin brought to the forefront of national discourse the topics of neologisms, portmanteaus, and linguistic slips when she used the word refudiate a handful of times in various contexts. Many were agog at the notion that anyone could misuse refute or repudiate (the words she was assumed to be combining), even though neither is particularly common. Palin, for her part, defended herself on Twitter, noting that English is a living language, and that Shakespeare was rather fond of coining new words as well.

In the article "Economics of American Domination" Margaret Heinemann writes about England as follows:

"Large American military and economic missions are permanently established in this country under the American Embassy, enjoying diplomatic privileges and Status, continuously "advising" Government department on the grounds that they are supervising the use of American aid." 
In this example, the verb to advise, enclosed in quotation marks, is a euphemism. Its function is ironic. It replaces the verb to order. Interestingly, the euphemism is put in quotation marks here or, in other words, expressed through a stylistic device of irony. The verb to advise is perceived as a euphemism. The irony here is incomplete. We can only speak of the ironic nature of the expression. The complete irony always assumes the opposite value. The verb to advise does not have the inverse meaning to order.

In English, there is a group of words called dysphemisms or cacofemisms. Their stylistic function is the opposite of that performed by euphemisms. They express the concept in a sharper and coarser form usually non-literary form - in comparison with the word that is attached to this concept. For example, the concept of death in English has the following cacofemisms: to kick the bucket, to go off the hooks and others. Such cacofemisms include the word benders instead legs, to be wrong in the upper storey instead to be mad and other.

The choice of a euphemism is caused by a specific expression in a specific context, without which we cannot determine whether a specific word (concept) is euphemistic or dysphemic. If a phenomenon or object belongs to those that are condemned by moral and social norms, then the euphemism does not last long, it loses the ability to neutralize the reaction to the word. Frequent use leads to a strengthening of associative links between old and new names and, therefore, the gradual transformation of euphemism in its opposite into the word taboo.

However, "leveling" (hence - the leveled, latent euphemism) is indicated in the sentence by the presence of two concepts - a soft euphemism and its denotation, which it replaces. The approximation of the meaning of the euphemism to its denotation does not occur immediately and not in all euphemisms, some words and phrases continue to be used (Oh, Lord!) with a minimally pronounced euphemistic function. Such euphemisms include euphemistic lexical-semantic categories, which denote god and deuce, which over time have lost their relationship with them and exist only to emotionally enhance expression. Modern English represents a large number of both euphemistic and dysphemic substitutes for the word "God".

If we consider the euphemistic substitution of the word "God", it is necessary to clearly define the difference between the concepts of profanity / blasphemy. Although the meaning of these words is to speak, to utter words of shame, to show disrespect for God or sacred things, the difference is that to slander often means in English to humiliate, laugh at the deity, his family or God's speakers - priests, other sacred attributes. Blasphemy at the same time uses religious terminology, with no intention of slander, but with careless disrespect. Therefore, the expression Jesus Christ is a blasphemy and can become blasphemous if the speaker intends to humiliate Christ.

In order to prevent blasphemy, a group of words appeared in the English language - euphemistic substitutions of the word-taboo, which formed their own, rather significant lexical-semantic group, the socalled exploitative.

The euphimization affected the words God!, Christ!, heaven, hell, devil, the latter are more often subject to dysphemisation (the process of acquiring the word (expression) signs of dysphemism - units with offensive, impolite connotations to be replaced by a neutral word (expression) or euphemism in modern linguistic research is opposed to the latter).

\section{CONCLUSIONS}

Based on the analysis of definitions of the concept of political correctness and approaches of scientists to the consideration of this phenomenon, two of its essential aspects are identified: socio-cultural (related to ideology and politics) and linguistic (search for new means of linguistic expression and adjustment of the linguistic code). Political correctness requires the use of technology to replace offensive terms with neutral words and expressions - euphemisms. Euphemisms can be classified according to several thematic fields in which they are used: euphemisms associated with groups of people who are discriminated; euphemisms denoting scary and unpleasant phenomena of reality; euphemisms associated with the influence of the state on people's lives; euphemisms denoting the appearance and age of people; euphemisms denoting the influence of people on flora and fauna; humorous euphemisms (parodies of political correctness).

As our study of 859 language units showed, the issues of racial discrimination are of the greatest importance for the tendency to political correctness: the vocabulary of the subgroup "racial, cultural, religious discrimination" is $21 \%$ of the total number of euphemisms.

Fighting gender discrimination represents a crucial importance for political correctness: the vocabulary of the subgroup "sex discrimination" is $19 \%$ of the actual material.

$9.7 \%$ of the actual material belongs to the subgroup "humorous euphemisms". This suggests that a large 
part of the population perceives political correctness ironically.

The subgroups "physical disabilities" $(4.5 \%)$ and "discrimination against sexual minorities" (3\%) are not represented by a very large number of politically correct euphemisms.

\section{REFERENCES}

[1] H. Beard, C. Cerf (eds.), The Official Politically Correct Dictionary and Handbook, Grafton, London, 1992.

[2] V.I. Hoverdovskyy, Experience of functional and typological description of connotation, dis. .. cand. philol. sciences, 1977.

[3] V.I. Karaban, Translation from Ukrainian into English, Nova Knyha, Vinnytsia, 2003, pp. 370382.

[4] O.Yu. Koltunov, Political correctness: analysis of definitions, Scientific notes: Collection. Political Science and Ethnology Series 26 (2004) 339345.

[5] N.G. Komlev, Dictionary of foreign words, EKSMO-Press, Moscow, 2006.

[6] O.I. Manyutina, Up to the problem of euphemia in contemporary English literature, Scientific bulletin of ChNU, Ruta, Chernivtsi, 2003, pp. 6372 .

[7] V.P. Moskvin, Euphemisms: Systemic connections, functions and methods of education, Linguistic issues 3 (2001) 58-70.

[8] D.V. Olshansky, Political and psychological dictionary, Academic project, Moscow, 2002.

[9] V.V. Panin, Euphemia in the system of ideological influence, in: Communication and language. Collection of articles of teachers and graduate students of the Faculty of Romance and Germanic Philology, Academy, Tyumen, 2002, pp. 85-86.

[10] O.S. Pasichnyk, Political correctness of language as a social phenomenon, in: Current issues of philology and translation studies: collection of works and reports All-Ukrainian Sciences Conf., May 12-13, 2005, KhNU, Khmelnytsky, 2005, pp. 112-113.

[11] A. Pauwels, Women Changing Language, Longman, London, 1998.
[12] S.G. Ter-Minasova, Language and intercultural communication, Slovo, Moscow, 2000.

[13] Z.S. Trofimova, Dictionary of new words and meanings in English, Pavlin, Moscow, 1993.

[14] L.V. Tsurikova, Socio-cultural conditioning of knowledge and analysis of discourse in intercultural communication, Bulletin of Voronezh State University, Series Linguistics and Intercultural Communication 2 (2001) 1725 . 